\title{
Study of Indonesia's International Macroeconomic Indicators Before and During The Covid-19 Pandemic
}

\author{
Dewi Mahrani Rangkuty \\ e-mail:dewimahrani@dosen.pancabudi.ac.id \\ Bakhtiar Efendi \\ e-mail: bakhtiarefendi@dosen.pancabudi.ac.id \\ Lia Nazliana Nasution \\ e-mail: lianazliana@dosen.pancabudi.ac.id \\ (Economics Department, Faculty of Social Science, Universitas Pembangunan Panca Budi, Medan)
}

\begin{abstract}
The Covid-19 pandemic has impacted changes in economic indicators in every country including Indonesia. This study aims to review Indonesia's macroeconomic indicators before and during the covid-19 pandemic. Using time-series data sourced from ceicdata, this study uses non-parametric statistical methods of different tests (sign tests). The results showed that there is a significant difference between before and during the covid-19 pandemic on international macroeconomic indicators of the rupiah exchange rate against USD, external debt, reserves, and Indonesian CPI. Recommended to the Government of Indonesia through Bank Indonesia and other relevant Ministries need a strict policy on a rupiah exchange rate that leads to price stability to reduce the rate of inflation, management and disclosure of external debt information, the achievement of trade balance surplus to increase reserves towards increasing domestic economic growth.
\end{abstract}

Keywords - Covid-19, Indicators, Macroeconomics, Pandemic

ABSTRAK: Pandemi Covid-19 telah berdampak pada perubahan indikator ekonomi di setiap negara termasuk Indonesia. Tujuan dari studi ini adalah untuk mengkaji indikator makroekonomi Indonesia sebelum dan selama pandemi covid-19. Dengan menggunakan data time series yang bersumber dari ceicdata, studi ini menggunakan metode statistik non parametrik uji beda (sign test). Hasil studi menunjukkan bahwa terdapat perbedaan yang signifikan antara sebelum dan selama pandemi covid-19 pada indikator makroekonomi internasional nilai tukar rupiah terhadap USD, external debt, reserves, dan cpi Indonesia. Direkomendasikan kepada pemerintah Indonesia melalui Bank Indonesia dan Kementerian terkait lainnya perlu kebijakan penjagaan ketat pada nilai tukar rupiah yang berujung pada kestabilan harga untuk menekan laju inflasi, pengelolaan dan keterbukaan informasi external debt, pencapaian surplus trade balance agar dapat menuju peningkatan reserves menuju peningkatan pertumbuhan ekonomi domestik.

Kata Kunci - Covid-19, Indikator, Makroekonomi, Pandemi 


\section{INTRODUCTION}

The pandemic of Covid-19 has an impact on the global economy, namely macro problems on the demand side of the supply side with very limited shocks, even the possibility of a global recession (Maital \& Barzani, 2020). Each country becomes an island in the world economy coordinated by the Covid-19 pandemic. The participation of countries around the world specifically focuses on open welfare and financial progress on which the objectives are based (Zekra, 2020). All major countries make decisions in favour of effectively increasing profits.

Indonesia's exports showed developments, especially to European and American countries. This means that Indonesia's exports are very important aimed at countries that are targeted or targeted. Long-term and short-term exchange rates have an impact on Indonesia's exports (Ginting, 2013). Exports are one of the factors that increase the economic growth of a country, in line with the export-led growth hypothesis (Ginting, 2017).

Figure 1 shows the difference in total export in the Covid-19 pandemic. Before was on May 2019 until February 2020 and during was on March until December 2020. Before and during were fluctuation, because this is related to the supply side that was disrupted due to Covid-19. Exports are low compared to other countries in the world, due in part to the implementation of policies that have not been by the theory (Suyatna, 2019). Exchange rate policy is important to trigger an increase in Indonesia's exports (Ginting, 2013). This policy also applies during the Covid-19 pandemic.
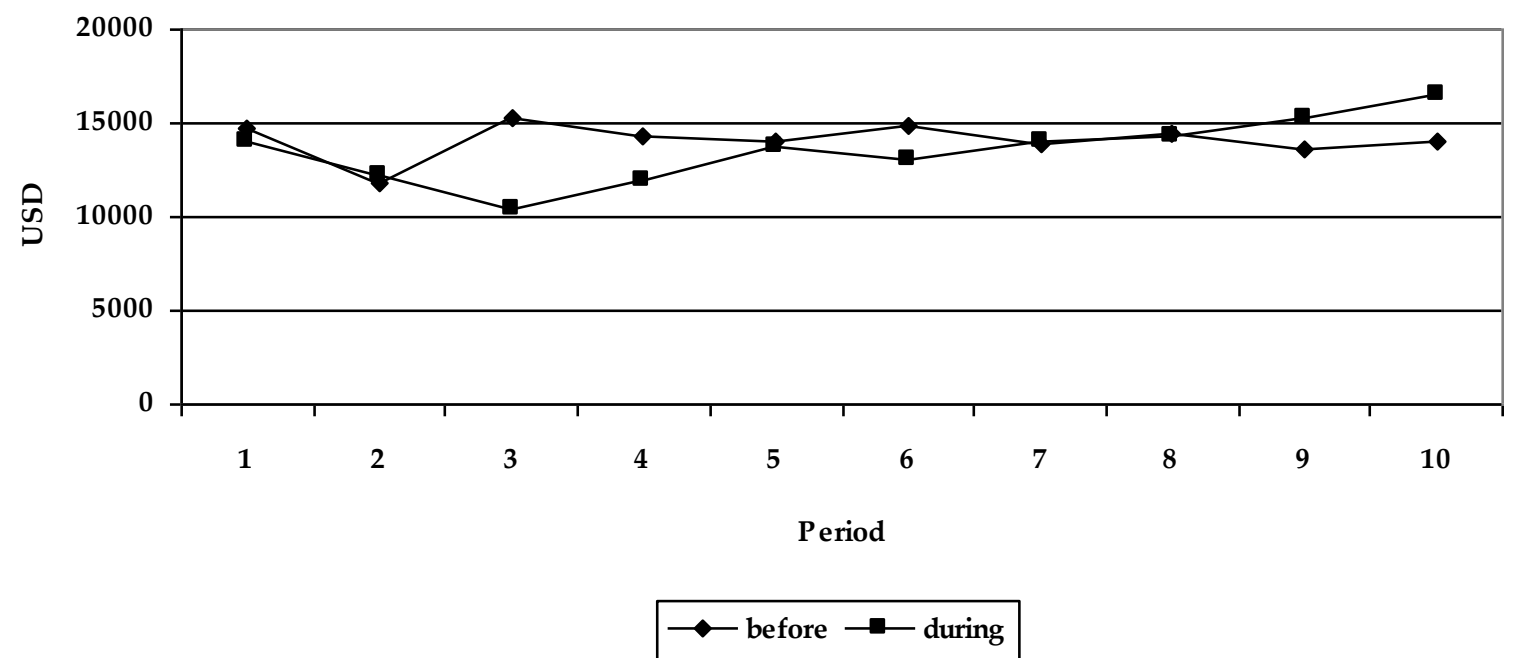

Figure 1. The Total Export of Indonesia Before and During The Covid-19 Pandemic

Source: (ceicdata, 2020d)

Exchange rates have an important impact on the economy. That is because one of the factors that can increase a country's national income is the positive difference between the export and import of a country. As in the formula of calculating national income where the consumption of a country, investment of a country, government expenditures, and positive differences from exports and imports of the country is a factor that affects national income. Exchange rates play a role in the export and import transactions of a country. The exchange rate is also the price of a currency measured by the currency of another country (Wowiling et al., 2016). Because the world has many different countries, their currencies are also different.

Bank Indonesia strives to maintain rupiah stability and continues to conduct a mixed strategy to support the national economic balance during the Covid-19 pandemic. This pandemic is likely to last a long time. Maintaining the balance of the rupiah exchange rate is not easy. The problem is not 
only when it is too low, but also when the rupiah value can be over-valued against other currencies. This depends on the situation at hand and the exchange rate system implemented (Hastuti \& Yahya, 2020).

Exchange rates are one of the elements considered by countries with an open economic system. Because a country with such a system that conducts international trade (Dzakiyah et al., 2018). No exception, it means that during the Covid-19 pandemic the exchange rate becomes an important element in export activities.

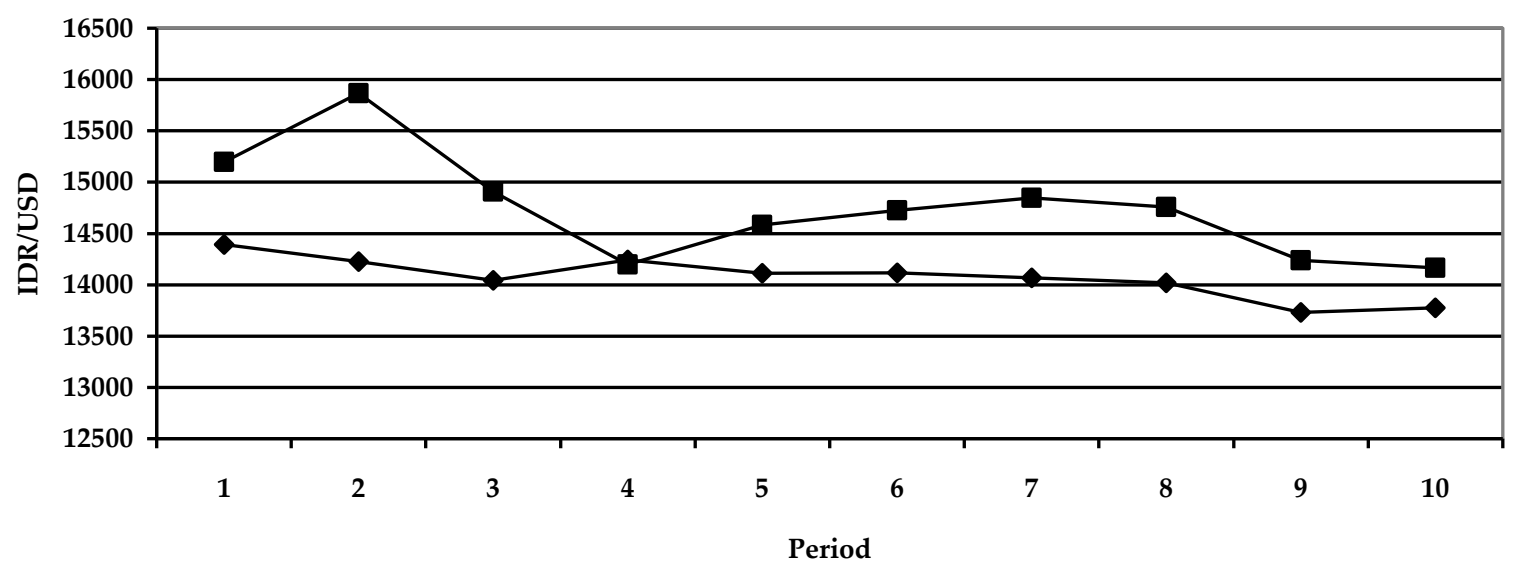

$$
\neg \text { before } \rightarrow-\text { during }
$$

Figure 2. The Exchange Rate of Indonesia Against USD Before and During The Covid-19 Pandemic Source: (ceicdata, 2020a)

Based on the figures, the exchange rate of IDR to USD before the Covid-19 pandemic is likely to appreciate while during the Covid-19 pandemic tends to depreciate. There is a significant difference between the rupiah exchange rate before and during the pandemic (Hastuti \& Yahya, 2020). The strengthening of IDR encourages an increase in Indonesia's export activities. 


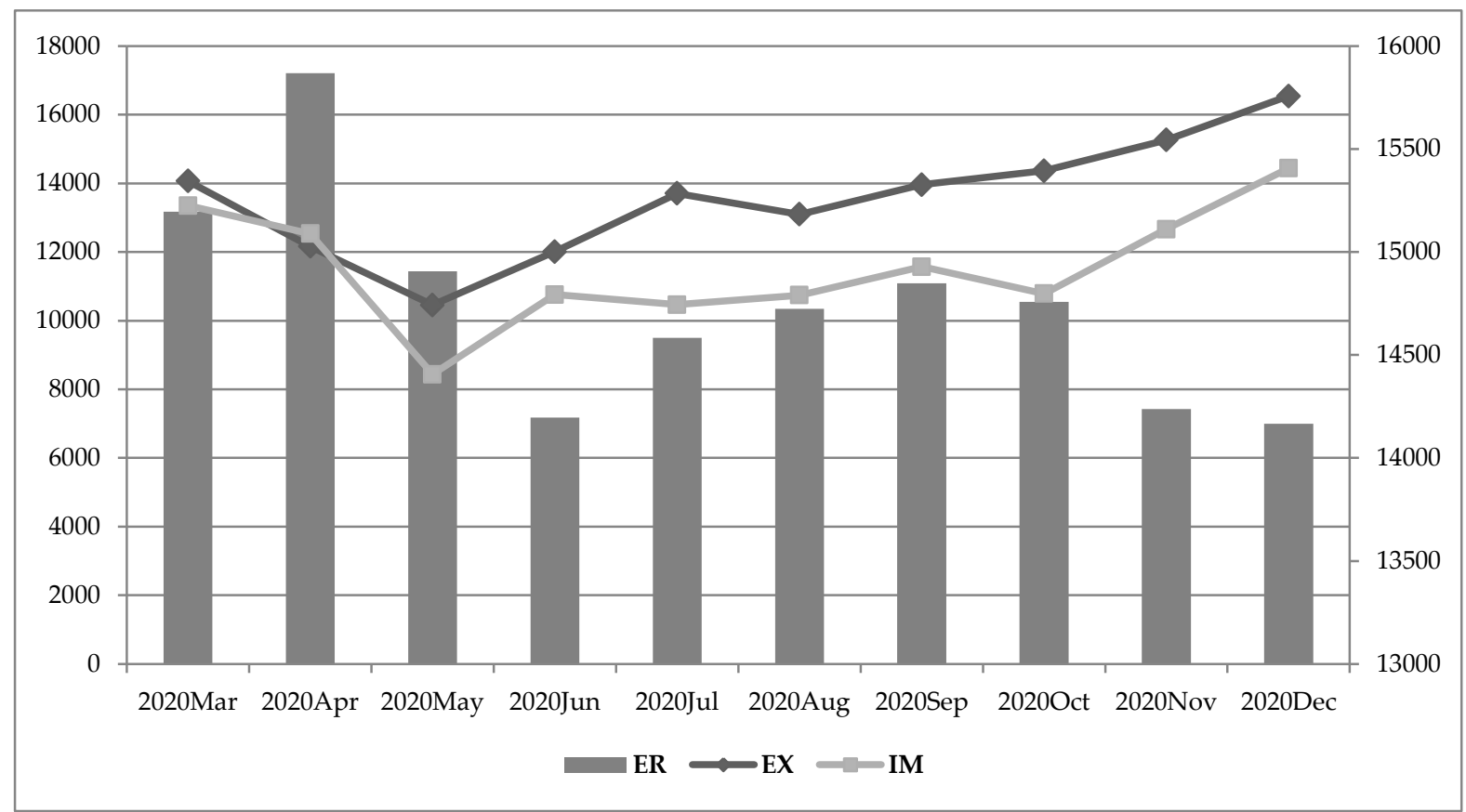

Figure 3. Total Export, Import and Exchange Rate During The Covid-19 Pandemic Source: (ceicdata, 2020c)

Indonesia's export-import development continues to be hunted during the Corona pandemic or COVID-19. Head of BPS Suhariyanto stated that the export achievement in May 2020 is the lowest since 2016, while the worst import position since 2009 (Thomas, 2020). Pandemic has an impact on the trade sector, especially exports and imports, raw materials and capital goods (Semaun, 2020). During the pandemic, Indonesia's exports and imports showed a negative trend in May 2020 and showed a positive trend in December 2020. This situation is accompanied by the condition of the IDR exchange rate against USD which tends to depreciate.

Thus, based on the data and results of previous researches the Covid-19 pandemic has had an impact on various Indonesian macroeconomic indicators that show differences in movement before and during the pandemic. Because of this phenomenon, the purpose is to find out and analyze the study of seven macroeconomic indicators of Indonesia before and during the Covid-19 pandemic.

\section{LITERATURE REVIEW}

This study uses international macroeconomic variables such as by definition, exports are activities to sell goods abroad while imports are activities to buy goods from abroad into the country (Sukrino, 2016). An exchange rate is a comparison of a country's currency exchange rate against another (Sonia \& Setiawina, 2016). Foreign debt is a loan of funds from other countries used for economic development in a country (BPK RI, 2011). Foreign exchange reserves are the value of profits obtained by a country from international trade activities (Yanto, 2018) where this is the result of the difference between exports and imports which is the trade balance (Sukrino, 2016). While the consumer price index is an indicator of the rate of inflation in a country (Masdjojo et al., 2016).

Exchange rates have an important impact on the economy. That is because one of the factors that can increase a country's national income is the positive difference between the export and import of a country. Exchange rates play a role in the export and import transactions of a country. An exchange rate is the price of a currency measured by another country's currency (Wowiling et al., 2016). Import activities are carried out as an effort to assist world countries in introducing their 
products in the international market because each country has different potentials and resources (Rangkuty, 2018). Exports, imports and exchange rates have a significant impact on Indonesia's foreign exchange reserves (Dananjaya et al., 2019).

The use of more productive external debt funds affects growth in a country (Kharusi \& Ada, 2018). The exchange rate against external debt is unpredictable (Bunescu, 2014). As one of the third countries, Indonesia also has foreign debt starting from the era of the old order until now. Initially, the debt was used to finance development but in the future in addition to development financing, foreign debt is also an additional budget deficit financing to spur desired economic growth (BPK RI, 2011).

Trade imbalances are generally associated with currency policy. The real exchange rate will adjust the trade balance. The Smithian-Harrodian theory explains that trade imbalances as a result of free trade and real competitiveness are not the same as the cause of trade imbalances (Shaikh \& Weber, 2018). While the consumer price index is one of the most important economic indicators for the characteristics of countries. CPI takes into account the price of a set of goods and services specified in a particular region and that is key in a country's economic and social planning (Riofrío et al., 2020). CPI is a macroeconomic indicator of countries as a function in the calculation of growth.

\section{METHODS}

Using time-series data sourced from CEIC is Global Macro and Micro Economic Data (www.ceicdata.com) from before and during the Covid-19 pandemic May 2019 to December 2020, this study uses the non-parametric statistic sign test method with SPSS v.23 software. Sign tests are used to test the differences between two pairs of samples if the data used is an ordinal scale, but the difference between the two pairs of measurements is not based on quantitative measurements but based solely on the direction of the difference (Suliyanto, 2014). This test is used if it is not possible to determine differences quantitatively, but can still determine differences between larger, smaller or equal pairs.

The Chi-Square test is used to test hypotheses with the following formula:

$$
x^{2}=\frac{(|n 1-n 2|)-(1)^{2}}{n 1+n 2}
$$

Where $\mathrm{n} 1$ shows the number of differences marked positive and $\mathrm{n} 2$ shows the number of differences marked negative. If a pair occurs ties or there is no difference, then the pair that occurs ties must be excluded from the analysis (Supranto, 2009), so that the sample size will be reduced. So, the number of pairs analyzed is the pair that has a sign of difference, either positive (+) or negative (-).

\section{RESULTS AND DISCUSSION}

Since the World Health Organization (WHO) announced the spread of the covid-19 virus as a health problem in the world (Zekra, 2020), the covid-19 pandemic has caused a global economic contraction that continues to this day resulting in uncertainty in global financial markets. Pandemics have an impact on sluggish economic activity in the market in some countries of the world. World trade volume and falling commodity prices, fiscal policy and monetary policy stimulus continue to be taken by many countries to minimize the risk of economic contraction (Anggarini \& Rakhmanita, 2020). This situation is what led to several international macroeconomic indicators changing.

International trade transactions are recorded in the trade balance or balance of payments; were transactions that cause the flow of foreign exchange from domestic to foreign countries are called negative transactions or debit transactions because these transactions lead to a decrease in the position of reserve assets. While transactions that cause the flow of foreign exchange from abroad 
into the country are called positive transactions or credit transactions because these transactions lead to an increase in the position of the country's foreign exchange reserves (Yanto, 2018).

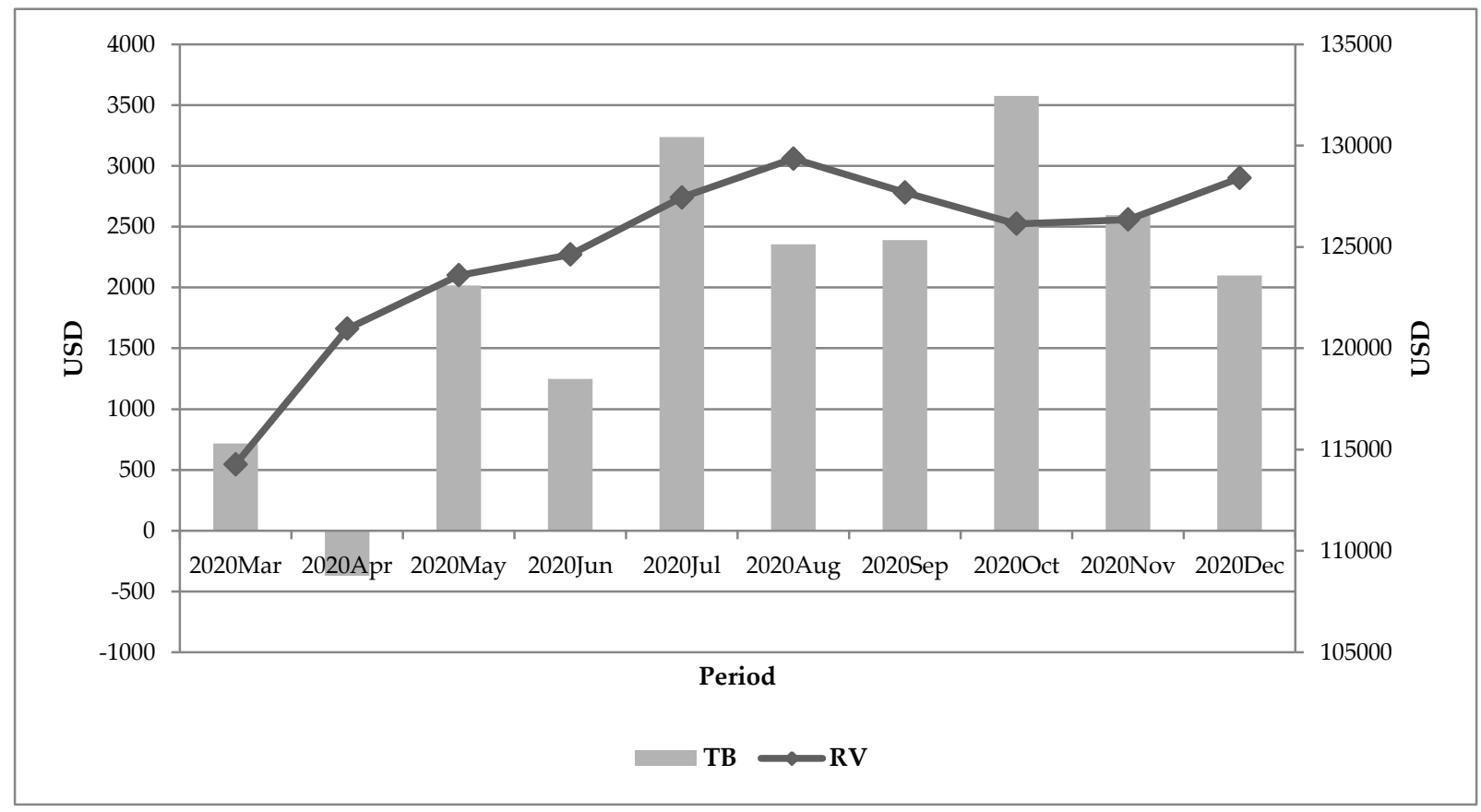

Figure 4. The Trade Balance and Reserves of Indonesia During The Covid-19 Pandemic

Source: (ceicdata, 2020e)

Foreign exchange reserves are assets or activities of central banks held in the form of foreign currencies. The size of the country's foreign exchange reserves depends on the strength of exports and imports both oil and gas and non-oil and gas (Asyaria et al., 2019). It is called the trade balance in which it is the difference between export and import.

The covid-19 pandemic has had an impact on changes in Indonesia's trade balance and other international macroeconomic indicators. The trade balance deficit during the pandemic resulted in a decrease in the value of Indonesia's foreign exchange reserves. The movement of Indonesia's trade balance and foreign exchange reserves data during the pandemic can be seen in Figure 4 .

It appears that the trend of movement of Indonesia's foreign exchange reserves during the pandemic follows the trend of trade balance movement. Deficit during the pandemic occurred in April 2020 and subsequently, there was a surplus. In March 2020 the reserves pandemic decreased significantly and then the trend shifted upwards and showed some positive growth. The country holds a higher amount of foreign exchange reserves than the level of adequacy (Agarwal et al., 2020). 


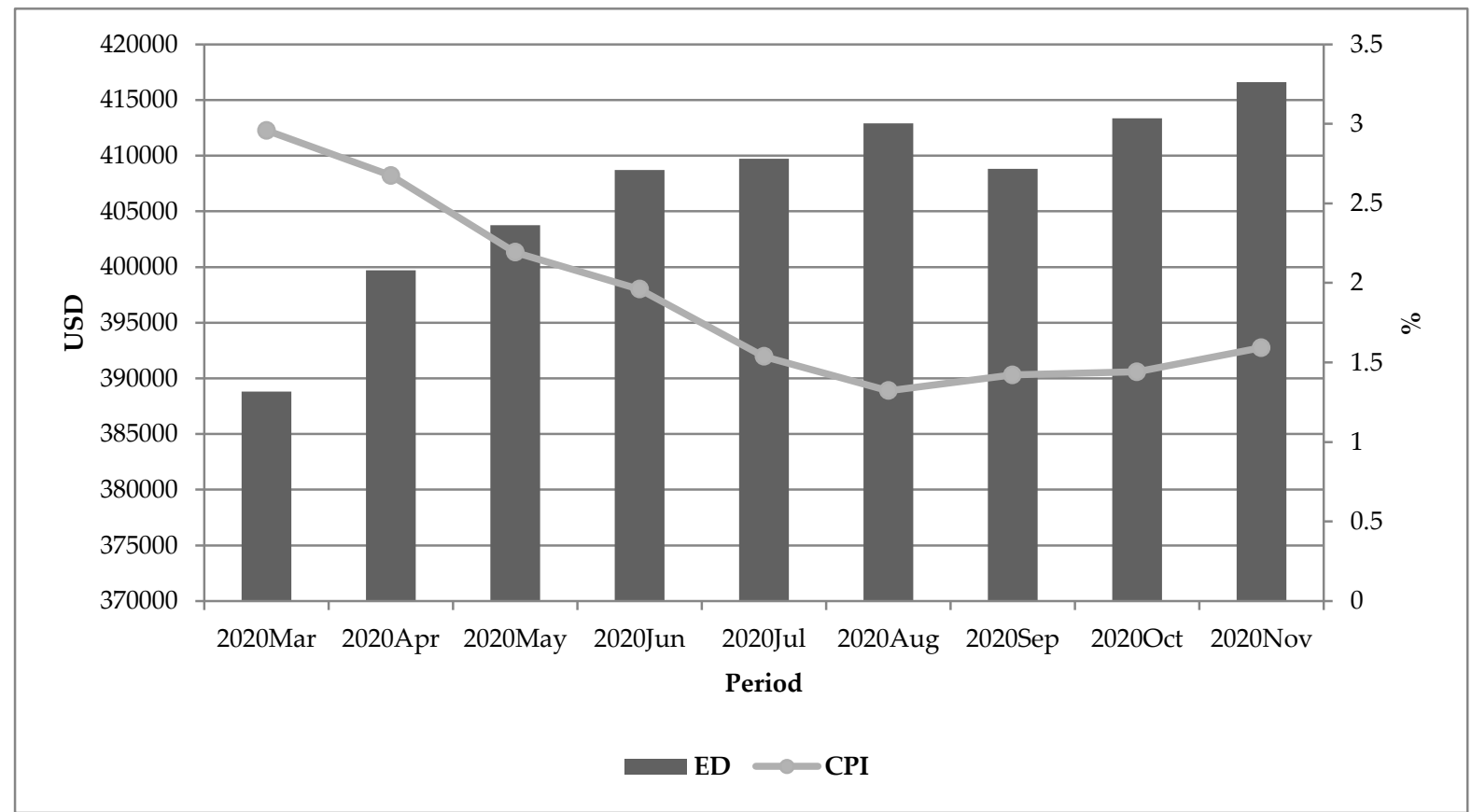

Figure 5. The External Debt and CPI of Indonesia During The Covid-19 Pandemic Source: (ceicdata, 2020b)

External debt is one of Indonesia's macroeconomic indicators. CPI as a macroeconomic indicator is used for the calculation of inflation in a country. Based on previous research on exports, imports and inflation have a significant association with foreign debt (Ristuningsih, 2016). Figure 5 shows the movement of Indonesia's external debt and CPI data during the covid-19 pandemic. External debt shows a positive trend while cpi shows a negative trend. Foreign debt affects inflation and vice versa inflation affects foreign debt (Rangkuty, 2019).

Table 1 is the sign test results of international macroeconomic indicators of Indonesia before and during the Covid-19 pandemic. The international macroeconomics indicators are export (EX), import (IM), the exchange rate (ER), external debt (ED), reserves (RV), trade balance (TB), and consumer price index (CPI).

The results of the sign test showed that before and during the covid-19 pandemic Indonesia's exports did not have significant differences. Before and during the covid-19 pandemic Indonesian imports did not have significant differences. Before and during the covid-19 pandemic the rupiah exchange rate against the USD had a significant difference. Before and during the covid-19 pandemic Indonesia's external debt had significant differences. Before and during the covid-19 pandemic Indonesia's reserves had significant differences. Before and during the covid-19 pandemic Indonesia's trade balance did not have significant differences. Before and during the covid-19 pandemic Indonesia cpi had significant differences.

There are significant differences between before and during the covid-19 pandemic on Indonesia's four international macroeconomic indicators. Namely at the exchange rate, external debt, reserves, and cpi. There is a significant difference between the exchange rate of rupiah before and during the Covid-19 pandemic (Hastuti \& Yahya, 2020). And the weakening of the rupiah against the US dollar continued in trade during the covid-19 pandemic (Andriani, 2020).

Table 1. Results of the Sign test 


\begin{tabular}{cc}
\hline Variables & Summary \\
\hline EX & $6^{*}$ \\
& $4^{* *}$ \\
IM & $(0.754)$ \\
& $8^{*}$ \\
& $2^{* *}$ \\
ER & $(0.109)$ \\
& $1^{*}$ \\
ED & $9^{* *}$ \\
& $(0.021)^{* * *}$ \\
RV & $0^{*}$ \\
& $9^{* *}$ \\
& $(0.004)^{* * *}$ \\
TB & $1^{*}$ \\
& $9^{* *}$ \\
& $(0.021)^{* * *}$ \\
CPI & $2^{*}$ \\
& $8^{* *}$ \\
& $(0.109)$ \\
& $10^{*}$ \\
& $0^{* *}$ \\
& $(0.002)^{* * *}$ \\
\hline
\end{tabular}

Source: data processed (2021); ${ }^{*}$ negative differences; ${ }^{* *}$ positive differences; *** significance at $5 \%$

Foreign debt policy or foreign loans are expected to help realize welfare for the community so that its management must be carried out responsibly (BPK RI, 2011). There is a significant difference between before and during the covid-19 pandemic shows that how important the policy of managing foreign debt by the Indonesian government is to prevent the hanging of other countries. Utilization of external resources from external debt in infrastructure development has a multiplier effect impact to bring profit by the state through national income to cover external debt payments from year to year.

Reserves show a causality relationship to the covid-19 pandemic. Changes in reserves value occur during pandemics (Cigdem, 2020). Reserves are the income of a country derived from international trade activities. The high reserves value as an international macroeconomic indicator of the country of Indonesia encourages the improvement of economic growth in the end. Reserves are increasing into a capital in paying external debt and domestic development. This situation proves that there is a significant difference between before and during the covid-19 pandemic on the value of Indonesia's reserves.

The covid-19 pandemic has resulted in widespread changes in household consumption patterns. How they spend their shopping time when a lockdown is applied. This situation makes the shopping pattern change and the rapid price change in some prices of goods and services so that people's cost of living changes during the pandemic (Blundell et al., 2020). So this situation reflects there is a significant difference between before and during the covid-19 pandemic in cpi. These macroeconomic indicators in Indonesia show significant differences during the pandemic. 


\section{CONCLUSION}

There is a significant difference between before and during the covid-19 pandemic on international macroeconomic indicators of the rupiah exchange rate against USD, external debt, reserves, and Indonesian cpi. Meanwhile, in Indonesia's export, import, and trade balance indicators, there is no significant difference between before and during the covid-19 pandemic. Hope to the next researchers to add variables with different research methods so that it can be a recommendation on policymaking by the Indonesian government. Recommended to the Government of Indonesia through Bank Indonesia and other relevant Ministries need a strict policy on a rupiah exchange rate that leads to price stability to reduce the rate of inflation, management and disclosure of external debt information, the achievement of trade balance surplus to increase reserves towards increasing domestic economic growth.

\section{REFERENCES}

Agarwal, K., Stradhar, P., \& Goswami, K. C. (2020). AN ANALYSIS OF RISING FOREIGN EXCHANGE RESERVES OF INDIA DURING THE COVID-19 PANDEMIC AND ITS POTENTIAL USE FOR ECONOMIC DEVELOPMENT. International Journal of Advanced Research in Engineering and Technology (IJARET), 11(7), 372-382.

http://www.iaeme.com/MasterAdmin/Journal_uploads/IJARET/VOLUME_11_ISSUE_7/IJARET _11_07_037.pdf

Andriani, R. S. (2020). WHO Tetapkan Virus Corona Pandemi Global, Kurs Rupiah Melemah - Market Bisnis.com. 12 Maret 2020.

Anggarini, D. T., \& Rakhmanita, A. (2020). Government Policies for Economic Recovery and Handling COVID -19 Virus in Indonesia. Moneter - Jurnal Akuntansi Dan Keuangan, 7(2), 140-146. https://doi.org/10.31294/moneter.v7i2.8548

Asyaria, K., Budiantoro, R. A., \& Herianingrum, S. (2019). Analisis Neraca Perdagangan Terhadap Cadangan Devisa di Indonesia (1975-2016). Jurnal Ekonomi, 24(2), 304-318.

https://www.researchgate.net/publication/338576784_Analisis_Neraca_Perdagangan_Terhadap_ Cadangan_Devisa_di_Indonesia_1975-2016

Blundell, R., Griffith, R., Levell, P., \& O'Connell, M. (2020). Could COVID-19 Infect the Consumer Prices Index?*. Fiscal Studies, 41(2), 357-361. https://doi.org/10.1111/1475-5890.12229

BPK RI. (2011). Utang Luar Negeri (No. 1; 1). https://jdih.bpk.go.id/wpcontent/uploads/2011/03/UtangLN.pdf

Bunescu, L. (2014). The impact of external debt on exchange rate variation in Romania. Economics and Sociology, 7(3), 104-115. https://doi.org/10.14254/2071-789X.2014/7-3/8

ceicdata. (2020a). Indonesia Exchange Rate against USD. Ceicdata.

https://www.ceicdata.com/id/indicator/indonesia/exchange-rate-against-usd

ceicdata. (2020b). Indonesia External Debt and Indonesia Consumer Price Index CPI Growth. Ceicdata. https://www.ceicdata.com/id/indicator/indonesia/external-debt

ceicdata. (2020c). Indonesia Total Export, Imports and The Exchange Rate of Indonesia Against USD.

Ceicdata. https://www.ceicdata.com/id/indicator/indonesia/total-imports

ceicdata. (2020d). Indonesia Total Exports. CEICDATA. 
https://www.ceicdata.com/id/indicator/indonesia/total-exports

ceicdata. (2020e). Indonesia Trade Balance and Indonesia Foreign Exchange Reserves. Ceicdata.

https://www.ceicdata.com/datapage/id/search?search_query=reserves indonesia

Cigdem, G. (2020). COVID-19 and net foreign exchange reserve relationship in Turkey: evidence from ARDL bounds testing approach. Pressacademia, 9(2), 80-96. https://doi.org/10.17261/pressacademia.2020.1216

Dananjaya, I. P. A. ., Jayawarsa, A. A. K., \& Purnami, A. A. S. (2019). Pengaruh Ekspor, Impor, Kurs Nilai Tukar Rupian, Dan Tingkat Inflasi Terhadap Cadangan Devisa Indonesia Periode 19992018. Warmadewa Economic Development Journal, 2(2), 64-71. https://www.ejournal.warmadewa.ac.id/index.php/wedj/article/view/1359

Dzakiyah, Z., Puspitaningtyas, Z., \& Puspita, Y. (2018). Pengaruh Jumlah Nilai Ekspor Dan Tingkat Inflasi Terhadap Kurs Rupiah Tahun 2009-2016. Jurnal Perilaku Dan Strategi Bisnis, 6(2), 103. https://doi.org/10.26486/jpsb.v6i2.559

Ginting, A. M. (2013). PENGARUH NILAI TUKAR TERHADAP EKSPOR INDONESIA. Buletin Ilmiah Litbang Perdagangan, 7(1), 1-18. http://jurnal.kemendag.go.id/bilp/article/view/96/61

Ginting, A. M. (2017). ANALISIS PENGARUH EKSPOR TERHADAP PERTUMBUHAN EKONOMI INDONESIA. Buletin Ilmiah Litbang Perdagangan, 11(1), 1-20. https://doi.org/10.30908/bilp.v11i1.185

Hastuti, P., \& Yahya, M. (2020). FENOMENA KURS RUPIAH SEBELUM DAN SELAMA COVID-19. NIAGAWAN, 9(3), 197. https://doi.org/10.24114/niaga.v9i3.18936

Kharusi, S. Al, \& Ada, M. S. (2018). External debt and economic growth: The case of emerging economy. Journal of Economic Integration, 33(1), 1141-1157. https://doi.org/10.11130/jei.2018.33.1.1141

Maital, S., \& Barzani, E. (2020). The global economic impact of COVID-19: A summary of research. Samuel Neaman Institute for National Policy Research, March 2020, 1-12. www.neaman.org.il

Masdjojo, G. N., Sugyanto, F. X., Myasto, \& Mariatmo, R. (2016). An empirical study of foreign exchange reserve through the balance of payment of Indonesia based on the Keynesian and the monetary approach. International Journal of Applied Business and Economic Research, 14(11), 76477674.

Rangkuty, D. M. (2018). ANALISIS KAUSALITAS DAN KOINTEGRASI ANTARA KURS DAN VOLUME IMPOR PROVINSI SUMATERA UTARA. Jurnal Ekonomi Dan Kebijakan Publik, 3(2), 52-58. http://jurnal.pancabudi.ac.id/index.php/jepa/article/view/324/305

Rangkuty, D. M. (2019). Analisis Utang Luar Negeri dan Inflasi Indonesia. Ekonomikawan, 19(1), 57-66. https://doi.org/https://doi.org/10.30596/ekonomikawan.v19i1.3240

Riofrío, J., Chang, O., Revelo-Fuelagán, E. J., \& Peluffo-Ordóñez, D. H. (2020). Forecasting the Consumer Price Index (CPI) of Ecuador: A comparative study of predictive models. International Journal on Advanced Science, Engineering and Information Technology, 10(3), 1078-1084. https://doi.org/10.18517/ijaseit.10.3.10813

Ristuningsih, S. (2016). Analisis faktor-faktor yang mempengaruhi utang luar negeri indonesia 
periode (1984-2013). Katadata, http://databoks.katadata.co.id/datapublish/2016/08.

Semaun, S. (2020). Dampak Pandemi Covid-19; Stimulus di Tengah Krisis Ekonomi Global. 12 April 2020. http://www.iainpare.ac.id/dampak-pandemi-covid-19-stimulus-di-tengah-krisis-ekonomiglobal/

Shaikh, A., \& Weber, I. (2018). The US-China trade balance and the theory of free trade: Debunking the currency manipulation argument. In The New School for Social Research, Working Paper 05/2018 (5). https://www.mendeley.com/catalogue/3466c7f6-28e4-39a9-b9fc-def12d664268/

Sonia, A., \& Setiawina, N. (2016). PENGARUH KURS, JUB DAN TINGKAT INFLASI TERHADAP EKSPOR, IMPOR DAN CADANGAN DEVISA INDONESIA. E-Jurnal Ekonomi Pembangunan Universitas Udayana, 5(10), 1077-1102.

https://ojs.unud.ac.id/index.php/eep/article/view/23551/16072

Sukrino, S. (2016). Teori Pengantar Makroekonomi. Rajawali Press.

Suliyanto. (2014). STATISTIKA NON PARAMETRIK dalam Aplikasi Penelitian (Yogyakarta). Penerbit ANDI.

Supranto, J. (2009). STATISTIK Teori dan Aplikasi (7th ed.). Erlangga.

Suyatna, U. (2019). Implementasi Kebijakan Ekspor Di Indonesia. Jurnal Ilmu-Ilmu Sosial Dan Humaniora, 21(2), 173-183. https://www.mendeley.com/catalogue/1fe4647e-0dff-330a-b9b4$1 \mathrm{~b} 2 \mathrm{fc} 137 \mathrm{e} 303 /$

Thomas, V. F. (2020). Babak Belur Ekspor \& Impor Indonesia di Tengah Pandemi COVID-19. Https://Tirto.Id/. https://tirto.id/babak-belur-ekspor-impor-indonesia-di-tengah-pandemi-covid19-fHME

Wowiling, L. G., Rotinsulu, T. O., \& Maramis, M. T. B. (2016). PENENTUAN TINGKAT KURS RUPIAH TERHADAP DOLLAR AMERIKA SERIKAT DI PASAR VALUTA ASING INDONESIA (PERIODE 1998.1-2014). JURNAL BERKALA ILMIAH EFISIENSI, 16(3), 758-763. https://www.mendeley.com/catalogue/8faba3c0-0369-309c-bc7c-45bde1ecd20f/

Yanto. (2018). CADANGAN DEVISA INDONESIA SEBAGAI SUATU FENOMENA MONETER: MODEL ANALISIS JALUR. Prosiding SATIESP 2018, 157-170. https://feb.untan.ac.id/wpcontent/uploads/2020/02/11.-Yanto.pdf

Zekra, L. (2020). COVID-19 Pandemic and Global Economic Impact. Ovidius University Annals, Economic Sciences Series, XX(1), 237-244. http://stec.univ-ovidius.ro/html/anale/RO/2020/Section 2/21.pdf 